\title{
The Response of Thurber's Needlegrass to Fall Prescribed Burning
}

\author{
Kirk W. Davies and Jonathan D. Bates
}

Authors are Rangeland Scientists, USDA-Agricultural Research Service, Eastern Oregon Agricultural Research Center, Burns, OR 97720, USA.

\begin{abstract}
Thurber's needlegrass (Achnatherum thurberianum [Piper] Barkworth) is an important component of many sagebrush communities in the Intermountain West. Prescribed fall burning is often implemented in sagebrush plant communities to mimic historic wildfires, improve wildlife habitat, and increase livestock forage production. Burning is used because it shifts dominance from sagebrush to herbaceous vegetation. The effects of prescribed fall burning on Thurber's needlegrass are largely unexplored. The purpose of this study was to determine the response of Thurber's needlegrass to prescribed fall burning. A randomized block design was used, and each block consisted of a fall burned and unburned (control) Wyoming big sagebrush (Artemisia tridentata subsp. wyomingensis [Beetle \& A. Young] S. L. Welsh)-bunchgrass communities. Response variables measured in the first and second years after burns were Thurber's needlegrass community foliar cover and density, vegetative and reproductive biomass, photosynthetic rates, tissue carbon $(\mathrm{C})$ and nitrogen $(\mathrm{N})$ content, and $\mathrm{N}\left({ }^{15} \mathrm{~N}:{ }^{14} \mathrm{~N}\right)$ and $\mathrm{C}\left({ }^{13} \mathrm{C}:{ }^{12} \mathrm{C}\right)$ isotope ratios. Density of Thurber's needlegrass in both postburn years and cover in the second postburn year were not different between treatments $(P>0.05)$, but cover was less in the burned than control treatment in the first postburn year $(P=0.008)$. Carbon isotope ratios in Thurber's needlegrass differed between the burn $(-25.9 \pm 0.1 \mathrm{SE})$ and control $(-26.3 \pm 0.1 \mathrm{SE})$ treatments in the first postburn year $(P=0.019)$. Nitrogen isotope ratios indicated nitrogen was more available in the burned than control treatment in both years $(P<0.05)$. Photosynthetic rates of Thurber's needlegrass were also generally greater in the burned than control treatment $(P=0.045)$. Our results suggest burning altered the availability of resources to Thurber's needlegrass plants. Our results also suggest that prescribed fall burning is not detrimental to Thurber's needlegrass and, thus, can be used as a method to shift dominance from sagebrush to herbaceous vegetation.
\end{abstract}

\section{Resumen}

La stipa Achnatherum thurberianum (Piper) Barkworth es un componente importante de muchas comunidades de artemisa en el oeste intermontano. La quema prescrita de otoño es aplicada a menudo en las comunidades de artemisa para simular fuegos forestales históricos, mejorar el hábitat de vida silvestre, y aumentar la producción de forraje para ganado. La quema es utilizada porque cambia la dominancia de artemisa a vegetación herbácea. Los efectos de la quema prescrita sobre la stipa todavía no han sido ampliamente explorados. El propósito de este estudio fue determinar la respuesta de stipa a las quemas prescritas de otoño. Un diseño de bloques al azar fue utilizado y cada bloque consistió de comunidades de Artemisa (Artemisia tridentata subsp. wyomingensis [Beetle \& A. Young] S. L. Welsh) con una quema de otoño y sin quema (control). La respuesta de las variables medidas en el primer y segundo año posterior a la quema fueron cobertura foliar y densidad de comunidades de stipa, biomasa vegetativa y reproductiva, tasas fotosintéticas, contenido en el tejido de carbono (C) y nitrógeno (N), y las relaciones de isótopos de $\mathrm{N}\left({ }^{15} \mathrm{~N}:{ }^{14} \mathrm{~N}\right)$ y $\mathrm{C}\left({ }^{13} \mathrm{C}:{ }^{12} \mathrm{C}\right)$. Las densidades y cobertura de stipa en los años posteriores a la quema no fueron diferentes entre tratamientos $(P>0.05)$, pero la cobertura fue menor en las áreas quemadas que en los tratamientos de control, posterior al primer año de quema $(P=0.008 \mathrm{SE})$. Las relaciones de isótopos de carbono en la stipa fueron diferentes entre los tratamientos de la quema $(-25.9 \pm 0.1 \mathrm{SE})$ y control $(-26.3 \pm 0.1 \mathrm{SE})$ en el primer año posterior a la quema $(P=0.019)$. Las relaciones de isótopos de nitrógeno indican que este esta mas disponible en las áreas quemadas que los tratamientos de control en ambos años $(P<0.05)$. Las tasas fotosintéticas de stipa fueron generalmente mayores en las áreas quemadas que el los tratamientos de control $(P=0.045)$. Nuestros resultados sugieren las quemas alteraron la disponibilidad de recursos para las plantas de stipa. Nuestros resultados también sugieren que la quema prescrita de otoño no es detrimental para la stipa, y por lo tanto, puedes ser utilizada como un método para cambiar la dominancia de la artemisa a vegetación herbácea.

Key Words: Achnatherum thurberianum, bunchgrass, disturbance, fire, isotopes, physiology

\section{INTRODUCTION}

The Eastern Oregon Agricultural Research Center is jointly funded by the USDA-Agricultural Research Service and Oregon State University Agricultural Experiment Station.

Mention of a proprietary product does not constitute a guarantee or warranty of the product by USDA, Oregon State University, or the authors and does not imply its approval to the exclusion of other products.

Correspondence: Kirk W. Davies, USDA-Agricultural Research Service, Eastern Oregon Agricultural Research Center, 67826-A Hwy 205, Burns, OR 97720, USA. Email: kirk.davies@ oregonstate.edu

Manuscript received 15 June 2007; manuscript accepted 16 November 2007.
Thurber's needlegrass (Achnatherum thurberianum [Piper] Barkworth) is a common perennial bunchgrass of sagebrush (Artemisia sp.) and dry forest communities in the Intermountain West (Hitchcock and Cronquist 1974). It may dominate or exist as a component of the herbaceous understory (Daubenmire 1970; Hironaka et al. 1983; Davies et al. 2006). Thurber's needlegrass is often found in association with Wyoming big sagebrush (Artemisia tridentata subsp. wyomingensis [Beetle \& 
A. Young] S. L. Welsh; Passey et al. 1982; Hironaka et al. 1983; Davies et al. 2006). The Wyoming big sagebrush alliance is the most extensive of the big sagebrush complex in the Intermountain West (Tisdale 1994) and is important for wildlife habitat, livestock production, biodiversity, and watershed function.

Fall, burning of Wyoming big sagebrush plant communities is prescribed to mimic historic fire-return intervals and to shift dominance from sagebrush to herbaceous vegetation to improve wildlife habitat and increase livestock forage production (Wright and Bailey 1982; Wirth and Pyke 2003; Davies et al. 2007). Wyoming big sagebrush is removed from the community with fall prescribed burning, and thus, herbaceous vegetation becomes dominant (Wright and Bailey 1982; Davies et al. 2007). However, the response of Thurber's needlegrass to fall prescribed burning is relatively unknown. Examining the response of Thurber's needlegrass to prescribed fall burning in Wyoming big sagebrush-bunchgrass communities is needed to provide information for land management, especially prescribed-burn planning, and to better understand these ecosystems and how disturbances affect plants at the individual and community level.

There are contradictions in the literature as to how Thurber's needlegrass responds to burning. Uresk et al. (1976) reported that, other than a reduction in basal area, burning had little negative effect on Thurber's needlegrass. In contrast, Uresk et al. (1980) measured a decrease in Thurber's needlegrass basal area, phytomass production, and shortened culms and spikes in response to burning. Britton et al. (1990) also reported a reduction in production from burning Thurber's needlegrass. Wright and Klemmedson (1965) reported Thurber's needlegrass often suffered mortality and a reduction in basal area from burning. Spring and early summer burns were more detrimental than later-season burns, and larger individuals were less resistant to burning than smaller plants (Wright and Klemmedson 1965). In agreement, Britton et al. (1990) measured only $10 \%$ mortality in Thurber's needlegrass with fall burning compared with $50 \%$ and $70 \%$ mortality from May and June burning, respectively. Fall prescribed burning may not negatively affect Thurber's needlegrass because burning in the fall would occur after anthesis. In southeastern Oregon, anthesis occurred in Thurber's needlegrass in August (Ganskopp 1988). Extrapolating the results of Uresk et al. (1976, 1980), Wright and Klemmedson (1965), and Britton (1990) to prescribed fall burning may not be appropriate. Uresk et al. (1976, 1980) measured Thurber's needlegrass response to wildfire, and Wright and Klemmedson (1965) and Britton et al. (1990) burned individual plants.

Thurber's needlegrass may respond positively to fall prescribed burning in sagebrush-bunchgrass communities because the competition or interference of sagebrush would be removed. Sagebrush competes or interferes with bunchgrass for soil nutrients and resources. Sagebrush is highly competitive for phosphorus $(\mathrm{P})$ relative to associated bunchgrasses (Caldwell et al. 1985, 1987, 1991), and herbage production tends to increase two- to threefold following sagebrush removal (Blaisdell 1953; Harniss and Murray 1973; Hedrick et al. 1966; Sneva 1972; Davies et al. 2007), suggesting a strong competitive interaction between sagebrush and herbaceous vegetation.
Prescribed burning may also increase soil nutrients (Ojima et al. 1994; Blair 1997). Davies et al. (2007) reported an increase in soil inorganic nitrogen the first $2 \mathrm{yr}$ after fall prescribed burning Wyoming big sagebrush-bunchgrass communities that contained Thurber's needlegrass. In contrast, Blank et al. (1994) reported a decrease in nitrate following a wildfire in a community dominated by sagebrush-cheatgrass (Bromus tectorum L.).

The purpose of this study was to determine the response of Thurber's needlegrass to fall prescribed burning in late-seral Wyoming big sagebrush-bunchgrass communities without invasive plant species. We hypothesized that Thurber's needlegrass density and cover in a community would initially decrease in response to burning, but that the production of surviving Thurber's needlegrass plants would increase because of greater resource availability. We also expected prescribed burning to increase Thurber's needlegrass photosynthetic rates and to discriminate against heavier carbon $(\mathrm{C})$ and nitrogen $(\mathrm{N})$ isotopes. In a review of several studies, Evans (2001) concluded discrimination against the heavier ${ }^{15} \mathrm{~N}$ isotope increased with greater nitrogen availability. $\mathrm{C}_{3}$ plants discriminate against the heavier ${ }^{13} \mathrm{C}$ isotope, allowing for a time-integrated estimate of water-use efficiency (Farquhar et al. 1989; Ehleringer et al. 1993), and discrimination increases with greater water availability (Toft et al. 1989).

\section{METHODS}

\section{Study Area}

The study was conducted at six sites on the Northern Great Basin Experimental Range (NGBER), which is located in southeastern Oregon (lat $43^{\circ} 29^{\prime} \mathrm{N}$, long $119^{\circ} 43^{\prime} \mathrm{W}$ ) about $56 \mathrm{~km}$ west of Burns, Oregon. The NGBER receives an average $300 \mathrm{~mm}$ of precipitation annually, which mainly comes in the fall, winter, and spring. Crop-year precipitation (1 October to 30 September) was $72 \%$ and $85 \%$ of the long-term average in 2002-2003 and 2003-2004, respectively (Eastern Oregon Agricultural Research Center, unpublished data, July 2006). Elevation at the study sites is approximately $1,400 \mathrm{~m}$ above sea level, and topography is flat (slopes $<2^{\circ}$ ). Soils across the study sites are a complex of Haploxerolls, Argixerolls, Durixerolls, and Durargids (Lentz and Simonson 1986). Wyoming big sagebrush is the dominant shrub, and Thurber's needlegrass, Idaho fescue (Festuca idahoensis Elmer), prairie junegrass (Koeleria macrantha [Ledeb.] J. A. Schultes), bluebunch wheatgrass (Pseudoroegneria spicata [Pursh] A. Löve), and squirreltail (Elymus elymoides [Raf.] Swezey) are common perennial bunchgrasses at the study area. Perennial bunchgrass dominance varies by site. Common forbs include long-leafed phlox (Phlox longifolia Nutt.), hawksbeard (Crepis sp. L.), curve-pod milkvetch (Astragalus curvicarpus [Heller] J. F. Macbr.), tailcup lupine (Lupinus candatus Kellogg), alyssum (Alyssum alyssoides [L.] L.), common yarrow (Achillea millefolium L.), and little blue-eyed Mary (Collinsia parviflora Lindl.).

\section{Experimental Design}

A randomized complete-block design was used to evaluate the effects of prescribed fall burning on Thurber's needlegrass. Six 
sites (blocks) with different soils and dominant herbaceous species were selected at the NGBER. Each block consisted of two $50 \times 80 \mathrm{~m}$ (0.4-ha) plots randomly assigned a burned or unburned (control) treatment. Preburn sampling revealed no differences in vegetation cover, density, or biomass between treatments $(P>0.05)$. The burned treatments were strip headfires applied between 1 and 6 October 2002, using a gel-fuel terra torch (Firecon, Inc., Ontario, OR). The fire removed sagebrush from the burned treatments. During the prescribed burns, wind speeds were between 8 and $20 \mathrm{~km} \cdot \mathrm{h}^{-1}$, air temperatures varied from $11^{\circ}$ to $26^{\circ} \mathrm{C}$, and relative humidity was between $10 \%$ and $36 \%$. Moisture contents of fine fuels (herbaceous vegetation) on a dry basis were between $8 \%$ and $12 \%$. Fine fuel amounts varied from 350 to $420 \mathrm{~kg} \cdot \mathrm{ha}^{-1}$. Response variables were Thurber's needlegrass community density and foliar cover, vegetative and reproductive biomass production, photosynthetic rates, tissue $\mathrm{C}$ and $\mathrm{N}$ content, $\mathrm{N}$ isotope ratio $\left({ }^{15} \mathrm{~N}:{ }^{14} \mathrm{~N}\right)$, and $\mathrm{C}$ isotope ratio $\left({ }^{13} \mathrm{C}:{ }^{12} \mathrm{C}\right)$.

\section{Sampling}

All response variables were sampled in 2003 and 2004, the first and second postburn years. Thurber's needlegrass community density and foliar cover were measured using 60 randomly located $0.4-\mathrm{m}^{2}$ frames per treatment replicate in June of each year. Density was measured by counting individuals, and foliar cover was measured by visual estimates in the $0.4-\mathrm{m}^{2}$ frames. Thurber's needlegrass vegetative and reproductive (seeds and seed heads) biomass production was measured by randomly selecting 10 Thurber's needlegrass plants to harvesting in late June in each treatment replicate. Each plant was randomly selected by generating two random numbers between 1 and 360. The first number generated was the direction in degrees, and the second number was the distance in paces to be traveled to select a Thurber's needlegrass plant. When the required distance in the selected direction had been traveled, the nearest Thurber's needlegrass was harvested. If the distance and direction selected intercepted the treatment replicate's plot boundary, the direction of travel was adjusted $90^{\circ}$ at the boundary to stay in the treatment replicate. Thurber's needlegrass plants were clipped, oven-dried, and separated into current and previous years' growth, and then, current year's growth was separated into vegetative and reproductive growth and weighed to determine biomass production. Photosynthetic rate was determined for six Thurber's needlegrass plants from each treatment replicate every 2 wk during the growing season using a LI 6200 Portable Photosynthesis Unit and a LI 2100 Leaf Area Meter (LI-COR, Inc., Lincoln, NE). Photosynthetic rate measurements were conducted at midday and on days without any cloud cover. Carbon and $\mathrm{N}$ isotope ratios and tissue $\mathrm{C}$ and $\mathrm{N}$ concentrations were measured from 10 Thurber's needlegrass individuals from each treatment replicate. Samples were collected in late June, ovendried, and separated into previous and current year's growth, and then, current year's growth was ground to pass through a 40-mesh screen. Ground samples were sent to the University of Utah Stable Isotope Research Facility for Environmental Research (Salt Lake City, UT) for analysis. The samples were analyzed using a Carla Erba 1108 elemental analyzer (Carla Erba, Milan, Italy) coupled with an open-split interface to a
Thermo Finnigan Delta S Isotope Ratio Mass Spectrometer (Finnigan MAT, Bremen, Germany).

\section{Statistical Analysis}

Repeated-measures analysis of variance (ANOVA) was used to test for treatment differences (SAS Institute 2001). Betweensubject effects were block and treatment. Within-subject effects were sampling date and the interactions of sampling date with between-subject effects. When response to treatment varied between the first and second year after burning, years were analyzed separately to simplify presentation and better illustrate the treatment effect on response variables. Analyzing years separately better illustrates treatment effects because there are often strong effect differences between first and second years after burning in sagebrush communities (Davies et al. 2007). Treatment effects in individual years and sampling dates were analyzed with ANOVA (SAS Institute 2001). Fisher Protected LSD was used to test for differences between means. Differences between means were considered significant if $P$ values were less than $0.05(\alpha=0.05)$. Means are reported with standard errors (mean \pm SE). Data that violated assumptions of normality were log-transformed. Data were back-transformed for presentation.

\section{RESULTS}

\section{Cover and Density}

Density and cover of Thurber's needlegrass response to treatments varied by year ( $P=0.038$ and 0.023 , respectively), so years were analyzed separately. Density was unaffected by prescribed fall burning in 2003 and $2004(P=0.112$ and 0.942 , respectively). In 2003, Thurber's needlegrass density in the burn and control was $1.5 \pm 0.2$ and $2.0 \pm 0.4$ individuals $\cdot \mathrm{m}^{-2}$, respectively. Densities in the burn and control were both $1.9 \pm 0.3$ individuals $\cdot \mathrm{m}^{-2}$ in 2004. Cover was less in the burn $(0.8 \pm 0.1 \%)$ than control $(2.1 \pm 0.3 \%)$ treatment in 2003 $(P=0.008)$; however, cover did not differ between the burn $(1.2 \pm 0.2 \%)$ and control $(1.6 \pm 0.3 \%)$ in $2004(P=0.080)$.

\section{Vegetative and Reproductive Biomass Production}

Vegetative biomass production was not different between treatments $(P=0.524$; Table 1$)$, but it was greater in 2004 than $2003(P=0.003)$. Vegetative biomass production response to treatment did not vary with year $(P=0.193)$. Reproductive biomass production and the ratio of reproductive to vegetative biomass production responses to treatment varied by year $(P<0.001$ and 0.013 , respectively); thus, each year was analyzed separately. Reproductive production was greater in the burned than control treatment in $2003(P<0.001)$; however, it did not differ between treatments in 2004 $(P=0.772)$. The ratio of reproductive to vegetative production was greater in the burned than control treatment in 2003 $(P<0.001)$, but it did not differ in $2004(P=0.140)$.

\section{Physiological Response}

Photosynthetic rates were generally greater in the burned than control treatment $(P=0.045$; Fig. 1$)$. Photosynthetic rates varied by sampling date $(P<0.001)$, but the response to 
Table 1. Biomass production of Thurber's needlegrass in the burned and control treatments in 2003 and 2004.

\begin{tabular}{|c|c|c|c|c|c|c|}
\hline \multirow[b]{2}{*}{ Characteristic } & \multicolumn{3}{|c|}{2003} & \multicolumn{3}{|c|}{2004} \\
\hline & Burned (mean $\pm \mathrm{SE}$ ) & Control (mean \pm SE) & Significance $^{1}$ & Burned (mean $\pm \mathrm{SE}$ ) & Control (mean \pm SE) & Significance \\
\hline $\begin{array}{l}\text { Vegetative biomass } \\
\left(\mathrm{g} \cdot \text { plant }^{-1}\right)\end{array}$ & $3.9 \pm 0.4$ & $3.6 \pm 0.5$ & NS & $5.8 \pm 0.6$ & $6.9 \pm 1.2$ & NS \\
\hline $\begin{array}{l}\text { Reproductive biomass } \\
\left(\mathrm{g} \cdot \text { plant }^{-1}\right)\end{array}$ & $0.4 \pm 0.1$ & $0.1 \pm 0.0$ & * & $0.6 \pm 0.1$ & $0.6 \pm 0.1$ & NS \\
\hline
\end{tabular}

${ }^{1}$ Significance for difference of means test. Asterisk $\left({ }^{*}\right)$ indicates significant difference $(P<0.05)$ in zonal means; NS, nonsignificant difference $(P>0.05)$.

treatment did not vary by sampling date $(P=0.755)$. The $\mathrm{N}$ isotope ratio was greater in the control than burned treatment in both years $(P=0.035$; Table 2$)$ and greater in 2003 than $2004(P=0.005)$. The response of the $\mathrm{N}$ isotope ratio to treatment did not vary by year $(P=0.290)$. Because the $C$ isotope ratio response to treatment varied by year $(P=0.019)$, each year was analyzed separately. The $\mathrm{C}$ isotope ratio was more negative in the control than burned treatment in 2003 $(P=0.009)$, but it did not differ between treatments in 2004 $(P=0.427)$. Tissue $\mathrm{N}$ concentration response to treatment varied with year $(P=0.049)$, so each year was analyzed individually. Tissue $\mathrm{N}$ concentration was not different between treatments in $2003(P=0.300)$ but was greater in the burned, compared with the control, treatment in $2004(P=0.008)$. Tissue $\mathrm{C}$ concentration did not vary with treatment $(P=0.322)$ but was greater in 2003 than $2004(P=0.016)$. Tissue $C$ concentration response to treatment did not vary with year $(P=0.564)$.

\section{DISCUSSION}

At the community level, Thurber's needlegrass had a limited response to the prescribed fall burn. The first year postburn, foliar cover of Thurber's needlegrass was lower in the burned than control treatments. By the second year postburn, cover did not differ between treatments. The greater cover in the control,

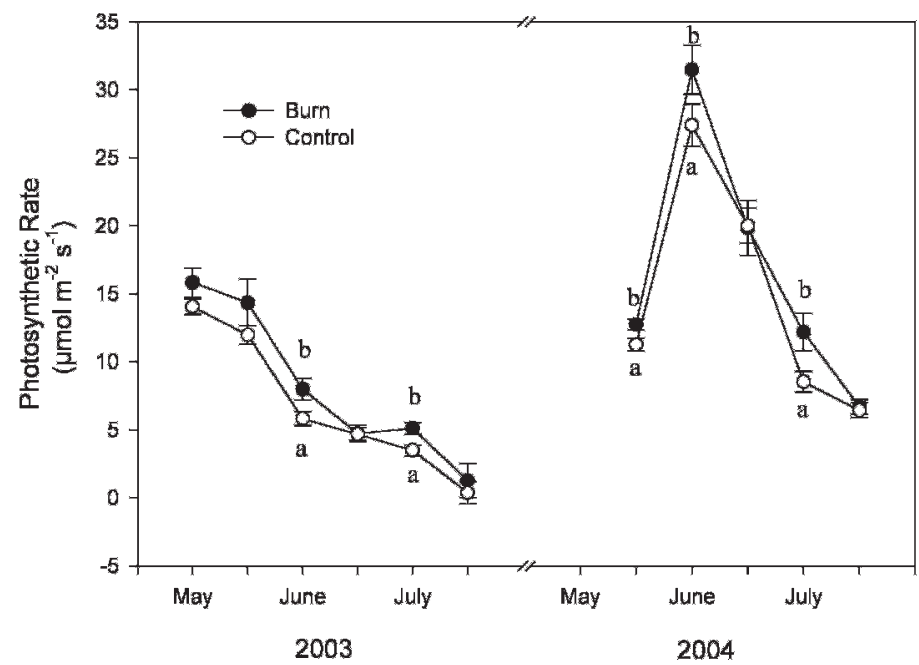

Figure 1. Photosynthetic rates (mean $\pm \mathrm{SE}$ ) of Thurber's needlegrass in the burned and control treatments in 2003 and 2004. Different lowercase letters indicate differences in photosynthetic rates between treatments on that sampling date $(P<0.05)$. compared with the burned, treatment was probably the result of the accumulation of previous years' growth. In the first year postburn, the burned treatment had only the current year's growth contributing to its cover value. However, earlier season wildfire and prescribed burns have been shown to reduce the basal area of Thurber's needlegrass (Wright and Klemmedson 1965; Uresk et al. 1976, 1980), which would potentially also reduce foliar cover. Density was not different between treatments in either year, suggesting that few Thurber's needlegrass plants suffered mortality. The lack of mortality among Thurber's needlegrass plants was probably because of the late seasonality of the prescribed burn. Thurber's needlegrass becomes more resistant to burning as the growing season progressed to anthesis (Wright and Klemmedson 1965).

Dissimilar to our hypothesis, Thurber's needlegrass plants did not produce more vegetative biomass with burning. However, in the first year postburn, Thurber's needlegrass plants from the burned treatment produced more reproductive biomass than the control treatment. Bailey and Anderson (1978), Patton et al. (1988), and Masters et al. (1993) reported that burning can increase reproductive biomass in grasses. However, the response of reproductive biomass to burning can vary by seasonality of the burn, species, year postburn, climate, and site (Bailey and Anderson 1978; Patton et al. 1988; Masters et al. 1993). Our results contradict research reporting a decrease in Thurber's needlegrass vegetative and reproductive production (Uresk et al. 1980; Britton et al. 1990). The contrast between our results and previous literature is probably because Thurber's needlegrass response to fire varies with the seasonality of the fire (Wright and Klemmedson 1965). Furthermore, Uresk et al. (1980) measured the response of Thurber's needlegrass to wildfire and Britton et al. (1990) burned Thurber's needlegrass plants individually. The wildfire documented by Uresk et al. (1980) occurred in mid-August, and Britton et al. (1990) burned individual Thurber's needlegrass plants in May, June, and November, whereas we measured the response of Thurber's needlegrass to prescribe burning in October. Our result may have differed from studies where Thurber's needlegrass plants were burned individually because burning plants individually may not accurately portray the effects of prescribed burning at the community level. When plants are burned individually, associated plant species would not experience the effects of the burning. Selective disturbances, such as individual burning plants, may favor the undisturbed plants over the disturbed plants. For example, selective grazing of grasses favored the growth of forbs in the tallgrass prairie (Fahnestock and Knapp 1994). Furthermore, burning sagebrush-bunchgrass communities shifts dominance from sagebrush to herbaceous vegetation because sagebrush is very 
Table 2. Carbon and nitrogen characteristics of Thurber's needlegrass in the burned and control treatments in 2003 and 2004.

\begin{tabular}{|c|c|c|c|c|c|c|}
\hline \multirow[b]{2}{*}{ Characteristic } & \multicolumn{3}{|c|}{2003} & \multicolumn{3}{|c|}{2004} \\
\hline & Burned (mean $\pm \mathrm{SE}$ ) & Control (mean \pm SE) & Significance $^{1}$ & Burned (mean $\pm \mathrm{SE}$ ) & Control (mean $\pm \mathrm{SE})$ & Significance \\
\hline${ }^{13} \mathrm{C}:{ }^{12} \mathrm{C}$ ratio (\%o) & $-25.9 \pm 0.1$ & $-26.3 \pm 0.1$ & * & $-26.5 \pm 0.1$ & $-26.4 \pm 0.1$ & NS \\
\hline${ }^{15} \mathrm{~N}:{ }^{14} \mathrm{~N}$ ratio (\%о) & $2.5 \pm 0.2$ & $3.4 \pm 0.5$ & * & $1.7 \pm 0.2$ & $2.0 \pm 0.2$ & * \\
\hline Total carbon (\%) & $42.3 \pm 0.3$ & $42.4 \pm 0.3$ & NS & $41.3 \pm 0.2$ & $41.6 \pm 0.1$ & NS \\
\hline Total nitrogen (\%) & $1.2 \pm 0.1$ & $1.2 \pm 0.1$ & NS & $1.2 \pm 0.1$ & $1.0 \pm 0.1$ & * \\
\hline
\end{tabular}

${ }^{1}$ Significance for difference of means test. Asterisk $\left({ }^{*}\right)$ indicates significant difference $(P<0.05)$; NS, nonsignificant difference $(P>0.05)$.

susceptible to fire, which would eliminate the competition or interference herbaceous species experience from sagebrush. For example, Davies et al. (2007) reported complete removal of sagebrush and an increase in herbaceous cover and production following prescribed burning of Wyoming big sagebrushbunchgrass communities. Similarly, burning completely removed sagebrush from our burned treatment.

Prescribed fall burning may alter the availability of resources to Thurber's needlegrass. Higher photosynthetic rates in the burned, compared with control, treatment suggest that, in general, resources were more available to Thurber's needlegrass after prescribed fall burning. Increased nitrogen availability (Gyuga et al. 2002) or water availability or both (Wingler et al. 1999; Lawlor and Cornic 2002) can result in higher photosynthetic rates. The greater discrimination against ${ }^{15} \mathrm{~N}$ in the burned, compared with the control, treatment suggests that nitrogen was more available after prescribed burning. Increasing nitrogen availability to plants allows them to discriminate against the heavier ${ }^{15} \mathrm{~N}$ isotope (Evans 2001). The increase in tissue nitrogen concentration in 2004 with burning also suggest more nitrogen was available to Thurber's needlegrass in the burned, compared with control, treatment. Increased nitrogen availability has been reported to increase plant tissue nitrogen concentration (Birk and Vitousek 1986). Similar to our results, increased plant tissue nitrogen concentrations with burning have been measured in big bluestem (Andropogon gerardi Vitman; Owensby et al. 1970) and pineland threeawn (Aristida stricta Michx; Christensen 1977). Although the nitrogen and photosynthetic data suggest a general increase in resource availability to Thurber's needlegrass with prescribed fall burning, the less discrimination against ${ }^{13} \mathrm{C}$ in the burned, compared with the control, treatment in the first year postburn suggests water was less available to Thurber's needlegrass with prescribed fall burning. Increasing water availability increases discrimination against the heavier ${ }^{13} \mathrm{C}$ isotope (Toft et al. 1989). Burning Wyoming big sagebrush-bunchgrass communities can decrease water content in the upper $30 \mathrm{~cm}$ of the soil profile, possibly due to reduced capture or increased evapotranspiration, in the first year postburn (Davies et al. 2007).

Our results suggest that prescribed fall burning has a limited impact on Thurber's needlegrass cover and density in the plant community. Prescribed fall burning did not negatively affect Thurber's needlegrass vegetative production, and it increased reproductive production in the first year postburn. The isotopic ratios, $\mathrm{N}$ tissue concentration, and photosynthetic data suggest that prescribed fall burning altered resource availability to Thurber's needlegrass. Although alterations in resource availability to Thurber's needlegrass were not all positive in the first year postburn, they suggest a general increase in resource availability with prescribed fall burning.

\section{MANAGEMENT IMPLICATIONS}

Under burn conditions similar to those in this study, prescribed fall burning can be used in late-seral Wyoming big sagebrushbunchgrass communities to shift dominance from sagebrush to herbaceous vegetation without negatively affecting Thurber's needlegrass. However, plant community dynamics following prescribed burning needs more and longer-term evaluation to fully understand the influence of fall burning on Thurber's needlegrass. Prescribed fall burning should not be implemented to increase Thurber's needlegrass because burning does not appear to have a substantial direct benefit to Thurber's needlegrass, and indirect benefits may be expressed over greater temporal intervals than the duration of this study, e.g., reduced sagebrush competition. Our results should not be extrapolated to wildfires or earlier-season prescribed burns. However, comparing our results to previous studies (Wright and Klemmedson 1965; Uresk et al. 1980; Britton et al. 1990) suggests that fall prescribed burning is a better management tool for shifting dominance from sagebrush to herbaceous vegetation than earlier-season burns. These results also apply only to late-seral Wyoming big sagebrush-bunchgrass communities without cheatgrass or other invasive plants. If invasive plants had been a component of the preburn community, our results may have been drastically different. The threat of invasive plants and potential impacts to sagebrush obligates should also be carefully considered before fall prescribed burning in sagebrush-bunchgrass communities.

\section{ACKNOWLEDGMENTS}

Assistance with plot setup and data collection by Dustin Johnson and Rob Sharp was greatly appreciated. The authors also thank the student summer range technicians for assisting with data collection. We also appreciate the thoughtful reviews of this manuscript by Jane Mangold, Mitchell Willis, and anonymous reviewers.

\section{LITERATURE CITED}

Balley, A. W., and M. L. Anderson. 1978. Prescribed burning of a Fescue-Stipa grassland. Journal of Range Management 31:446-449.

BIRK, E. M., AND P. M. Vitousek. 1986. Nitrogen availability and nitrogen use efficiency in loblolly pine stands. Ecology 67:69-79. 
BLAIR, J. M. 1997. Fire, N availability, and plant response in grasslands: a test of the transient maxima hypothesis. Ecology 78:2359-2368.

BLAISDELL, J. P. 1953. Ecological effects of planned burning sagebrush-grass range on the Upper Snake River Plains. Washington, DC, USA: United States Department of Agriculture, Technical Bulletin 1075. 34 p.

Blank, R. R., F. Allen, and J. A. Young. 1994. Extractable anions in soils following wildfire in a sagebrush-grass community. Soil Science Society of America Journal 58:564-570.

Britton, C. M., G. R. McPherson, and F. A. Sneva. 1990. Effects of burning and clipping on five bunchgrasses in eastern Oregon. Great Basin Naturalist 50:577-583.

Caldwell, M. M., D. M. Eissenstat, J. H. Richards, and M. F. Allen. 1985. Competition for phosphorus: differential uptake from dual-isotope-labeled soil interspaces between shrub and grass. Science 229:384-386.

Caldwell, M. M., J. H. Manwaring, and R. B. Jackson. 1991. Exploitation of phosphate from fertile soil microsites by three Great Basin perennials when in competition. Functional Ecology 5:757-764.

Caldwell, M. M., J. H. Richards, J. H. Manwaring, and D. M. Eissenstat. 1987. Rapid shifts in phosphate acquisition showing direct competition between neighboring plants. Nature 327:615-616.

Christensen, N. L. 1977. Fire and soil-plant nutrient relationships in a pinewiregrass savanna on the coastal plains of North Carolina. Oecologia 31:27-44.

Daubenmire, R. 1970. Steppe vegetation of Washington. Pullman, WA, USA: Washington State University. Bulletin 62. 131 p.

Davies, K. W., J. D. Bates, and R. F. Miller. 2006. Vegetation characteristics across part of the Wyoming big sagebrush alliance. Rangeland Ecology \& Management 59:567-575.

Davies, K. W., J. D. Bates, and R. F. Miller. 2007. Short-term effects of burning Wyoming big sagebrush steppe in southeast Oregon. Rangeland Ecology \& Management 60:515-522.

Ehleringer, J. R., A. E. Hall, and G. D. Farquhar. 1993. Stable isotope and plant carbon-water relations. San Diego, CA, USA: Academic Press. 555 p.

Evans, R. D. 2001. Physiological mechanisms influencing plant nitrogen isotope composition. Trends in Plant Science 6:121-126.

Fahnestock, J. T., and A. K. Knapp. 1994. Plant responses to selective grazing by bison: interactions between light, herbivory and water stress. Plant Ecology 115:123-131.

Farquhar, G. D., J. R. Ehleringer, and K. T. Hubrick. 1989. Carbon isotope discrimination and photosynthesis. Annual Review of Plant Physiology and Plant Molecular Biology 40:503-537.

Ganskopp, D. 1988. Defoliation of Thurber needlegrass: herbage and root response. Journal of Range Management 41:472-476.

Gyuga, P., A. L. Demagante, and G. M. Paulsen. 2002. Photosynthesis and grain growth of wheat under extreme nitrogen nutrition regimes. Journal of Plant Nutrition 25:1281-1290.

HaRniss, R. O., And R. B. MurRay. 1973. 30 years of vegetal change following burning of sagebrush-grass range. Journal of Range Management 26:322-325.

Hedrick, D. W., D. N. Hyder, F. A. Sneva, and C. E. Poulton. 1966. Ecological response of sagebrush-grass range in eastern Oregon to mechanical and chemical removal of Artemisia. Ecology 47:432-439.
Hironaka, M. M., M. Fosberg, and A. H. Winward. 1983. Sagebrush-grass habitat types of southern Idaho. Bulletin 35. Moscow, ID, USA: University of Idaho. 41 p.

Hitchcock, C. L., And A. Cronquist. 1974. Flora of the Pacific Northwest. Seattle, WA, USA: University of Washington Press. $730 \mathrm{p}$.

LaWloR, D. W., and G. Cornic. 2002. Photosynthetic carbon assimilation and associated metabolism in relation to water deficits in higher plants. Plant, Cell, and Environment 25:275-294.

Lentz, R. D., And G. H. Simonson. 1986. A detailed soils inventory and associated vegetation of Squaw Butte Range Experiment Station. Corvallis, OR, USA: Oregon State University, Oregon Agricultural Experiment Station Special Report 760.

Masters, R. A., R. B. Mitchell, K. P. Vogel, and S. S. Walker. 1993. Influence of improvement practices on big bluestem and indiangrass seed production in tallgrass prairies. Journal of Range Management 46:183-188.

OJima, D. S., D. S. Schimel, W. J. PARTon, And C. E. OWensby. 1994. Long- and shortterm effects of fire on nitrogen cycling in tallgrass prairie. Biogeochemistry 24:67-84.

Owensby, C. E., G. M. Paulsen, and J. D. McKendrick. 1970. Effects of burning and clipping on big bluestem reserve carbohydrates. Journal of Range Management 23:353-362.

Passey, H. B., V. K. Hugie, E. W. Williams, and D. E. Ball. 1982. Relationships between soil, plant community, and climate on rangelands of the intermountain west. Washington, DC, USA: United States Department of Agriculture, Soil Conservation Service, Technical Bulletin 1662. 52 p.

Patton, B. D., M. Hironaka, and S. C. Bunting. 1988. Effects of burning on seed production of bluebunch wheatgrass, Idaho fescue, and Columbia needlegrass. Journal of Range Management 41:232-234.

SAS Institute. 2001. SAS/STAT user's guide. Version 8. Cary, NC, USA: SAS Institute.

Sneva, F. A. 1972. Grazing return following sagebrush control in eastern Oregon. Journal of Range Management 25:174-178.

Tisdale, E. W. 1994. Wyoming big sagebrush SRM 403. In: T. N. Shiflet [ed.]. Rangelands cover types of the United States. Denver, CO, USA: Society for Range Management. p. 42-43.

Toft, N. L., J. A. Anderson, and R. S. Nowak. 1989. Water use efficiency and carbon isotope composition of plants in a cold desert environment. Oecologia 80:11-18.

Uresk, D. W., J. F. Cline, and W. H. Rickard. 1976. Impact of wildfire on three perennial grasses in south-central Washington. Journal of Range Management 29:309-310.

Uresk, D. W., W. H. Rickard, and J. F. Cline. 1980. Perennial grasses and their response to a wildfire in south-central Washington. Journal of Range Management 33:111-114.

Wingler, A., W. P. Quick, R. A. Bungard, K. J. Bailey, P. J. Lea, and R. C. Leegood. 1999. The role of photorespiration during drought stress: an analysis utilizing barley mutants with reduced activities of photorespiratory enzymes. Plant, Cell, and Environment 22:361-373.

Wirth, T. A., And D. A. Pyke. 2003. Restoring forbs for sage grouse habitat: fire, microsites, and establishment methods. Restoration Ecology 11:370-377.

Wright, H. A., AND A. W. Balley. 1982. Fire ecology: United States and southern Canada. New York, NY, USA: John Wiley and Sons. p. 159-160.

Wright, H. A., And J. O. KLemmedson. 1965. Effect of fire on bunchgrasses of the sagebrush-grass region in southern Idaho. Ecology 46:680-688. 